\title{
Effect of Ridge Lap Surface Treatment and Thermocycling on Microtensile Bond Strength of Acrylic Teeth to Denture Base Resins
}

\author{
Carolina de Andrade Lima CHAVES ${ }^{1}$ \\ Rômulo Rocha REGIS ${ }^{2}$ \\ Ana Lucia MACHADO ${ }^{1}$ \\ Raphael Freitas de SOUZA ${ }^{2}$ \\ ${ }^{1}$ Department of Dental Materials and Prosthodontics, Araraquara Dental School, \\ São Paulo State University, Araraquara, SP, Brazil \\ ${ }^{2}$ Department of Dental Materials and Prosthodontics, Ribeirão Preto Dental School, \\ University of São Paulo, Ribeirão Preto, SP, Brazil
}

\begin{abstract}
This study evaluated the effect of denture base polymer type (heat- and microwave-polymerized), ridge lap surface treatment (with and without methyl methacrylate-MMA etching) and thermocycling on the microtensile bond strength ( $\mu$ TBS) of Biotone acrylic teeth. Flat-ground, ridge-lap surface of posterior artificial teeth were bonded to cylinders of each denture base resin, resulting in the following groups ( $\mathrm{n}=6$ ): G1a - Clássico/with MMA etching; G1b - Clássico/without MMA etching; G2a - OndaCryl/with MMA etching; G2b - OndaCryl/without MMA etching. Rectangular bar specimens with a cross-sectional area of $1 \mathrm{~mm}^{2}$ were prepared. Half of the bars in each group were thermocycled $\left(5,000\right.$ cycles between $4^{\circ} \mathrm{C}$ and $\left.60^{\circ} \mathrm{C}\right) . \mu \mathrm{TBS}$ testing was performed in an universal testing machine at a crosshead speed of $0.5 \mathrm{~mm} / \mathrm{min}$. Data were analyzed statistically by three-way ANOVA $(\alpha=0.05)$. There was no statisticaly significant difference $(\mathrm{p}>0.05)$ for the factors (resin, surface treatment, and thermocycling) or their interactions. The mean $\mu$ TBS values (MPa) and standard deviations were as follows: Thermocycling - G1a: 41.00 (14.00); G1b: 31.00 (17.00); G2a: 50.00 (27.00); G2b: 40.00 (18.00); No thermocycling - G1a: 37.00 (14.00); G1b: 43.00 (25.00); G2a: 43.00 (14.00); G2b: 40.00 (27.00). The $\mu$ TBS of Biotone artificial teeth to the denture base acrylic resins was not influenced by the polymer type, surface treatment or thermocycling.
\end{abstract}

Key Words: acrylic resins, artificial tooth, surface treatment, microtensile bond strength.

\section{INTRODUCTION}

Acrylic denture teeth have been widely used in removable prosthodontics due to their advantages over porcelain teeth, which include ease of adjustment, reduced cost, ability to bond to denture bases and higher shock absorbability (1). In recent years, implant-supported prosthesis, particularly mandibular overdentures, have provided predictable results in the prevention of bone loss, improved stability, retention, function and quality of life compared to conventional dentures (2). Because of the increase in the number of implant-supported dentures, the use of acrylic denture teeth has also increased markedly $(3,4)$.
The debonding of acrylic teeth from the denture base remains a common clinical occurrence in prosthodontic practice (3), involving $22 \%$ to $30 \%$ of denture repairs (5). In addition, as the implant-supported dentures improve the masticatory function, acrylic resin artificial tooth debonding from the denture base may be increased (4). Tooth detachment from the denture base resins may be attributed to several factors, including the direction of functional forces (5), the ridge lap area available for bonding with the base resin (5), contamination of the denture teeth with wax or tin foil substitute (6), ridge lap modification, denture base resin dough stage at the packing time, length or cycle of polymerization of the denture base resin, and chemical treatment of the ridge 
lap area of the acrylic resin denture teeth (7).

In an attempt to estimate the adhesion of artificial teeth to denture base acrylic resins, different methods have been used, such as tensile/compression loading (8-11), 4-point flexure tests (12) and finite element stress analysis (5). In the majority of the studies, the bond strength between denture base acrylic resins and denture teeth was evaluated by a shearing test (8-10). The results from these studies were depending on the type of materials used, and some combinations of denture base materials and artificial teeth were found to be more compatible and exhibited superior bond strength (8-10).

Previous studies have suggested that microtensile bond strength ( $\mu \mathrm{TBS}$ ), with reduced testing area, may be more appropriate to evaluate the bond strength of resin composite bonded to ceramic (adhesive interfaces) due to the more uniform distribution of the interfacial stresses (13). In addition, the microtensile test has been used as the first-choice method to determine the bond strength of interfaces between other dental materials (13). However, fewer studies had evaluated the $\mu$ TBS of artificial teeth to acrylic base resins (4).

The aim of this study was to evaluate the effect of denture base polymer type, ridge lap surface treatment and thermocycling on the $\mu \mathrm{TBS}$ of a commercial brand of acrylic denture teeth. The research hypothesis tested was that the $\mu$ TBS of the artificial teeth would not be affected by the denture base polymer type, ridge lap surface treatment or thermocycling.

\section{MATERIAL AND METHODS}

Denture acrylic resin posterior teeth $30 \mathrm{M}$ occlusal type 33 degrees (Biotone; Dentsply ind. Com. Ltda., Petrópolis, RJ, Brazil) and 2 acrylic resin denture base materials: a conventionally water-bath cured (Clássico; Clássico Artigos Odontológicos Ltda., São Paulo, SP, Brazil) and a microwaved (Onda Cryl; Clássico Artigos Odontológicos Ltda.) were tested.

All acrylic artificial teeth were flattened with 600,800 and 1000 -grit silicon carbide paper under water cooling in a polishing machine (DPU-10; Panambra Ind. e Técn. S.A., São Paulo, SP, Brazil).
The teeth were fixed with wax on a glass slab with the prepared flat surfaces facing down and surrounded by polyvinyl chloride (PVC) rings (18 $\mathrm{mm}$ height, $17 \mathrm{~mm}$ diameter). Afterwards, the PVC tubes were poured with type IV dental stone (Herostone; Vigodent S/A Ind Com, Rio de Janeiro, RJ, Brazil) under vibration. After stone setting, the sets were removed from the glass slab, the tubes cut longitudinally with carborundum disks, the stone blocks containing the embedded teeth carefully removed from the tubes, and placed on a glass slab with the prepared flat surfaces facing up.

A second PVC ring was positioned over the stone block, encircling the tooth sample, and filled with melted wax. The stone-tooth-wax sets were invested longitudinally in type III dental stone (Herodent; Vigodent S/A Ind. Com.) in a metallic flask (OGP Produtos Odontológicos Ltda, São Paulo, SP, Brazil).

After the stone set, 2 coats of sodium alginate (Cel-Lac, Dentsply Ind Ltda, Petrópolis, RJ, Brazil) were applied to the stone surfaces. The upper part of the flask was filled with dental stone (Herodent). The flask was pressed with a hydraulic press (Delta Máquinas Especiais, Vinhedo, SP, Brazil) with a load of 1,250 $\mathrm{kgf}$ for $60 \mathrm{~min}$, and afterwards placed in boiling water for $10 \mathrm{~min}$ to soften the wax. The flask was opened, and the softened wax was boiling out with detergent (Limpol; Bom-Bril, São Bernardo do Campo, SP, Brazil) to prevent any contamination of the bonding surfaces.

The acrylic resins were handled according to the manufacturers' recommendations (Table 1), and left to polymerize for approximately $15 \mathrm{~min}$ at $23^{\circ} \mathrm{C}$ until dough stage was reached. Before resin packing, the teeth from groups G1a and G2a had their exposed surface painted during 1 min with their respective monomer (MMA -

Table 1. Denture base acrylic resins and curing protocols.

\begin{tabular}{ccccc}
\hline $\begin{array}{c}\text { Acrylic } \\
\text { resin }\end{array}$ & $\begin{array}{c}\text { Batch \# } \\
\text { (monomer } / \\
\text { polymer })\end{array}$ & Curing & $\begin{array}{c}\text { Polymerization } \\
\text { method }\end{array}$ & $\begin{array}{c}\text { Powder:liquid } \\
\text { ratio (g:mL) }\end{array}$ \\
\hline Clássico & $\begin{array}{c}220207 / \\
711070\end{array}$ & $\begin{array}{c}\text { water-bath } \\
\text { polymerization }\end{array}$ & $7^{\circ} \mathrm{C}$ for $9 \mathrm{~h}^{*}$ & $21: 7$ \\
Onda Cryl & $150107 /$ & $\begin{array}{c}\text { microwave } \\
\text { polymerization }\end{array}$ & $\begin{array}{c}320 \mathrm{~W} \text { for } 3 \text { min } \\
0 \mathrm{~W} \text { for } 4 \text { min } \\
720 \mathrm{~W} \text { for } 3 \text { min }\end{array}$ & $21: 7$ \\
\hline
\end{tabular}

*Barbosa et al. (14); **Manufacturer's instructions. 
surface treatment). The resins were packed and polymerized in an automatic polymerization unit (Ribeirão Preto Dental School, Ribeirão Preto, SP, Brazil) or domestic microwave oven (ME28S; Electrolux SA, Manaus, AM, Brazil) according to the protocol described in Table 1. After conventional polymerization, the flasks were kept in the curing unit until the water reached room temperature $(15,16)$, and the microwaved flask was bench cooled (17). After deflasking, the specimens were stored in distilled water at $37^{\circ} \mathrm{C}$ for 7 days (4).

The following groups were formed $(n=6)$ : $(\mathrm{G} 1 \mathrm{a})$ Clássico/with MMA etching; (G1b) Clássico/without MMA etching; (G2a) OndaCryl/with MMA etching; (G2b) OndaCryl/without MMA etching.

\section{Specimen Preparation}

Each tooth-acrylic resin set (Fig. 1) was serially sectioned to obtain rectangular specimens with mean cross-sectional area of $1 \mathrm{~mm}^{2}$. The sections were cut parallel to the long axis of the tooth and perpendicular to the bonding interface using a low-speed (100 rpm) with a water-cooled diamond saw (Isomet; Buehler, LakeBluff, IL, USA). Half of the specimens were randomly assigned and subjected to 5,000 thermal cycles, in baths at $4^{\circ} \mathrm{C}$ and $60^{\circ} \mathrm{C}$, for $30 \mathrm{~s}$ at each temperature. The remaining specimens were not thermocycled.

\section{$\mu$ TBS Testing}

The width and thickness of the specimens were

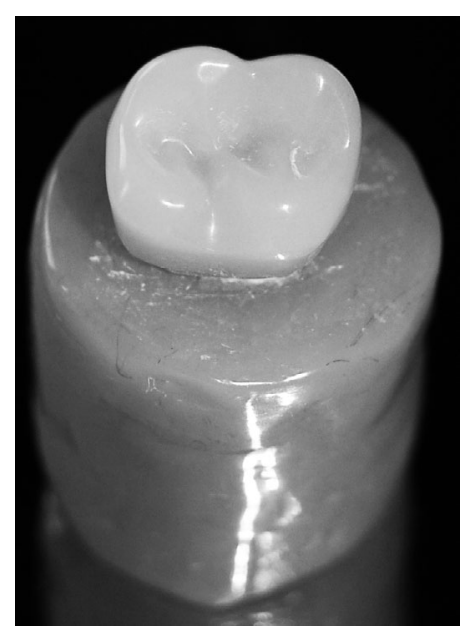

Figure 1. Tooth-acrylic resin set. measured with a digital caliper (Mitutoyo Corp., Kawasaki, Japan), and the bonded area was calculated $\left(1 \mathrm{~mm}^{2}\right)$. Each specimen was fixed in a metallic holding set with cyanoacrylate adhesive (Super Bonder; Loctite Henkel Ltd, Diadema, SP, Brazil), taken to a universal testing machine (DL-1000; EMIC Equipamentos e Sistemas de Ensaio Ltda, São José dos Pinhais, PR, Brazil) and calibrated with a $1 \mathrm{KN}$ load cell. The tensile load was applied perpendicular to the long axis of the specimen at a cross-head speed of $0.5 \mathrm{~mm} / \mathrm{min}$ until failure.

The bond strength $\left(\mathrm{kgf} / \mathrm{cm}^{2}\right)$ was calculated using the following equation: $\mathrm{R}=\mathrm{F} / \mathrm{A}$, where " $\mathrm{R}$ " is the $\mu \mathrm{TBS}$, " $F$ " the load (Kgf) required for specimen failure, and "A" the interface area $\left(\mathrm{mm}^{2}\right)$ of the specimens. The results in $\mathrm{kgf} / \mathrm{cm}^{2}$ were changed to MPa multiplying by the constant 0.098 .

Three-way ANOVA was used to analyze the factors (acrylic resin, surface treatment and thermocycling) and their interactions. The means were analyzed by Tukey's test $(\alpha=0.05)$. All calculations were performed with statistical software (SPSS 12.0.0 for Windows; SPSS Inc, Chicago, IL, USA).

\section{RESULTS}

Figure 2 presents graphically the results from the $\mu \mathrm{TBS}$ testing for the groups. There was no statistically significant effect of the factors (acrylic resin: $\mathrm{F}=2.52$, $\mathrm{p}=0.115$; surface treatment: $\mathrm{F}=2.09, \mathrm{p}=0.151$; and thermocycling: $\mathrm{F}=0.00, \mathrm{p}=0.978$ ) or their interactions ( $>0.05$ ) on the $\mu$ TBS of the acrylic teeth to the denture base resins.

\section{DISCUSSION}

The failure of the bond between acrylic resin

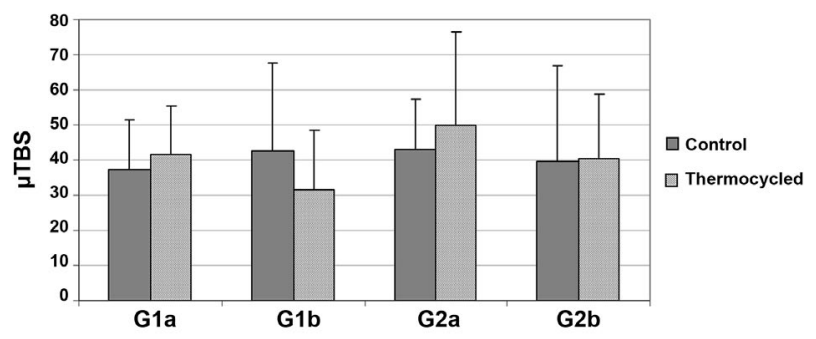

Figure 2. Mean $\mu$ TBS values of the groups. Error bars represent standard deviations. 
teeth and denture base material remains a clinical concern. However, it can be minimized by means of adequate bond strength between acrylic teeth and the resin base. It has been demonstrated that type of acrylic resin, method of polymerization, tooth surface conditioning, and thermal stress can influence the resin/tooth bond $(8-10,18)$. Therefore, this study investigated whether the $\mu \mathrm{TBS}$ of the Biotone artificial teeth would be influenced by factors such as denture base polymer type, bond surface treatment or thermocycling.

Some approaches have been proposed for improving the bond strength between artificial teeth and denture base, as coating the tooth with monomer or other chemical agent, before packing the resin $(11,18)$. The constitution of the bonding agents should provide a mild solvent effect on the ridge lap tooth structure, and allow adequate polymer cross-linking at the tooth-resin interface (6). Saavedra et al. (4) evaluated the adhesion between acrylic teeth and heat-polymerized acrylic resin using a microtensile test on teeth subjected to different surface treatments. The results showed that the bond strength was significantly affected by the surface treatments, with the methyl methacrylate-based adhesive showing the highest bond strength. In contrast, the findings of the present study demonstrated that wetting the ridge lap surface with denture base acrylic resin monomer did not significantly influence the results. One possible explanation for these differences could be based on the composition of the chemical products used for etching the tooth bonding surfaces. While the monomer of the denture base acrylic resins is composed mainly by MMA, Vitacol contains MMA and a solvent (butanone). Therefore, when MMA is used as bonding agent may not enhance the bond between denture teeth and acrylic resin similarly to the commercial products developed specifically for this purpose. Vallitu et al. (19) evaluated the strength of heat-cured acrylic resin repaired specimens. The repair surfaces of the specimens were etched with methyl methacrylate for several times before the autopolymerizing acrylic resin was applied to the bond area. Those authors reported that the acrylic surface wetting with MMA, before the resin curing, dissolves the surface structure of the denture base resin, and that monomer etching for $180 \mathrm{~s}$ improved the adhesion due to a smoother surface texture when compared to that obtained with shorter wetting times. In the present study, the denture base resin monomer was applied to the ridge lap surfaces with a brush during $60 \mathrm{~s}$. It is likely that the shorter application time was not sufficient to cause a significant effect on the $\mu$ TBS results.

In this study, thermocycling was used to simulate intraoral conditions more closely. This heating-cooling process may result in repeated expansion and contraction of the tooth and acrylic resin, stressing the bonding area and decreasing the bond strength. In addition, according to Schneider et al. (20), the hydration of the specimens further simulates the clinical condition. However, the results of this study showed that there was no statistically significant difference between thermocycled and nonthermocycled specimens for all groups evaluated. These findings are in disagreement with the results from previous investigations $(4,9)$. Saavedra et al. (4) evaluated the $\mu$ TBS between acrylic teeth and a heat-polymerized acrylic resin at dry and thermocyled conditions (60 days water storage followed by 12,000 cycles). Those authors found that the bond strength was significantly affected by the storage conditions (dry>thermocycled). Marra et al. (9) observed that thermocycling resulted in a significant decrease in the shear bond strength between a heat-polymerized denture base acrylic resin and Biotone denture teeth. Conversely, the results of this investigation are in accordance with those reported by Barbosa et al. (10), who verified that the shear bond strength of Onda-Cryl and Clássico resins to the Biotone denture teeth was not significantly affected by thermocycling. The differences between the current results and those reported by Saavedra et al. (4) and Marra et al. (9) could be attributed to the number of thermocycles and different materials used. The lower number of cycles employed in the present study, as compared to those used by Saavedra et al. (4), may not have stressed the interface sufficiently to reduce the bond strength. In the study of Marra et al. (9), a different brand of heat-polymerized denture base acrylic resin (Lucitone 550) was used.

The number of thermal cycles and bond surface treatment are some limitations of this study. In addition, only one type of denture teeth and 2 denture base acrylic resins of the several available materials were tested. Hence, further studies including other materials, ridge lap surface treatments, and number of thermal cycles are recommended. Nevertheless, considering that insufficient information is available regarding the use of microtensile bond test to evaluate the bond between teeth and denture base acrylic resins, the present results may provide additional information.

Within the limitations of this in vitro study, it 
may be concluded that the $\mu$ TBS of the Biotone acrylic teeth to Clássico and OndaCryl denture base acrylic resins was not influenced by the material, surface treatment or thermocycling regimen.

\section{RESUMO}

Este estudo avaliou o efeito do tipo de resina de base (termopolimerizada e polimerizada por microondas), tratamento da superfície de união (com e sem aplicação de metil metacrilato) e

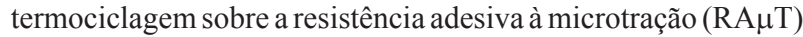
do dente artificial Biotone. A superfície cervical dos dentes foi desgastada para se obter superfícies planas, as quais foram unidas a cada uma das resinas, constituindo os seguintes grupos $(\mathrm{n}=6)$ : (G1a) Clássico/com MMA; (G1b) Clássico/sem MMA; (G2a) OndaCryl/com MMA; (G2b) OndaCryl/sem MMA. Corpos-deprova retangulares com área transversal de $1 \mathrm{~mm}^{2}$ foram preparados. Metade dos espécimes em cada grupo foi termociclado $\left(5000\right.$ ciclos de $4^{\circ} \mathrm{C}$ a $\left.60^{\circ} \mathrm{C}\right)$. $\mathrm{O}$ teste de resistência adesiva foi realizado numa máquina de ensaios universal (velocidade da carga: $1 \mathrm{~mm} / \mathrm{min}$ ). Os dados foram analisados estatisticamente por meio da ANOVA para 3 fatores $(\alpha=0,05)$. Os valores médios de RA $\mu$ T e desvios-padrão foram: Termociclagem - G1a: 41,00 $(14,00)$; G1b: 31,00 (17,00); G2a: 50,00 (27,00); G2b: 40,00 $(18,00)$; Sem termociclagem - G1a: 37,00 (14,00); G1b: 43,00 $(25,00) ;$ G2a: 43,00 (14,00); G2b: 40,00 (27,00). A RA RT entre os dentes artificiais e as resinas acrílicas para base de prótese não foi influenciada pelos fatores resina acrílica, tratamento de superfície ou termociclagem.

\section{ACKNOWLEDGEMENTS}

The authors would like to thank Mr. Edson Volta and Mr. Ricardo Antunes for their assistance with the microtensile bond strength testing.

\section{REFERENCES}

1. Kawano F, Ohguri T, Ichikawa T, Mizuno I, Hasegawa A. Shock absorbability and hardness of commercially available denture teeth. Int J Prosthodont 2002;15:243-247.

2. Doundoulakis JH, Eckert SE, Lindquist CC, Jeffcoat MK. The implant-supported overdenture as an alternative to the complete mandibular denture. J Am Dent Assoc 2003;134:1455-1458.

3. Patil SB, Naveen BH, Patil NP. Bonding acrylic teeth to acrylic resin denture bases: a review. Gerodontology 2006;23:131-139.
4. Saavedra G, Valandro LF, Leite FPP, Amaral R, Ozcan M, Bottino MA, et al. Bond strength of acrylic teeth to denture base resin after various surface conditioning methods before and after thermocycling. Int J Prosthodont 2007;20:199-201.

5. Darbar UR, Huggett R, Harrison A. Denture fracture - a survey. Br Dent J 1994;176:342-345.

6. Cunningham JL, Benington IC. A new technique for determining the denture tooth bond. J Oral Rehabil 1996;23:202-209.

7. Cunningham JL, Benington IC. An investigation of the variables which may affect the bond between plastic teeth and denture base resin. J Dent 1999;27:127-135.

8. Geerts GAVM, Jooster CH. A comparison of the bond strengths of microwave and water bath cured denture material. J Prosthet Dent 1990;70:406-409.

9. Marra J, Souza RF, Barbosa DB, Pero AC, Compagnoni MA. Evaluation of the bond strength of denture base resins to acrylic resin teeth. The effect of thermocycling. J Prosthodont 2009; 18:438-443.

10. Barbosa DB, Barão VA, Monteiro DR, Compagnoni MA, Marra J. Bond strength of denture teeth to acrylic resin: effect of thermocycling and polymerisation methods. Gerodontology 2008;25:237-244.

11. Chung KH, Chung CY, Chung CY, Chan DC. Effect of preprocessing surface treatments of acrylic teeth on bonding to the denture base. J Oral Rehabil 2008;35:268-275.

12. Kawara M, Carter JM, Ogle RE, Johnson RR. Bonding of plastic teeth to denture base resins. J Prosthet Dent 1991;66:566-571.

13. Della Bona A, Anusavice KJ, Mecholsky Jr JJ. Failure analysis of resin composite bonded to ceramic. Dent Mater 2003;19:693-699.

14. Barbosa DB, Compagnoni CA, Leles CR. Changes in occlusal vertical dimension in microwave processing of complete dentures. Braz Dent J 2002;13:197-200.

15. Consani RL, Mesquita MF, Consani S, Correr Sobrinho L, SousaNeto MD. Effect of water storage on tooth displacement in maxillary complete dentures. Braz Dent J 2006;17:53-57.

16. Consani RL, Domitti SS, Mesquita MF, Consani S. Influence of flask closure and flask cooling methods on tooth movement in maxillary dentures. J Prosthodont 2006;15:229-234.

17. Consani RLX, Lira AF, Mesquita MF, Consani S. Linear dimensional change in acrylic resin disinfected by microwave energy Braz Dent Sci 2006;9:34-39.

18. Cunningham JL. Shear bond strength of resin teeth to heat-cured and light-cured denture base resin. J Oral Rehabil 2000;27:312-316.

19. Vallittu PK, Alakuijala P, Lassila VP, Lappalainen R. In vitro fatigue fracture of an acrylic resin-based partial denture: an exploratory study. J Prosthet Dent 1994;72:289-295.

20. Schneider RL, Curtis ER, Clancy JMS. Tensile bond strength of acrylic resin denture teeth to a microwave - or heat-processed denture base. J Prosthet Dent 2002;88:145-150.

Accepted February 5, 2009 